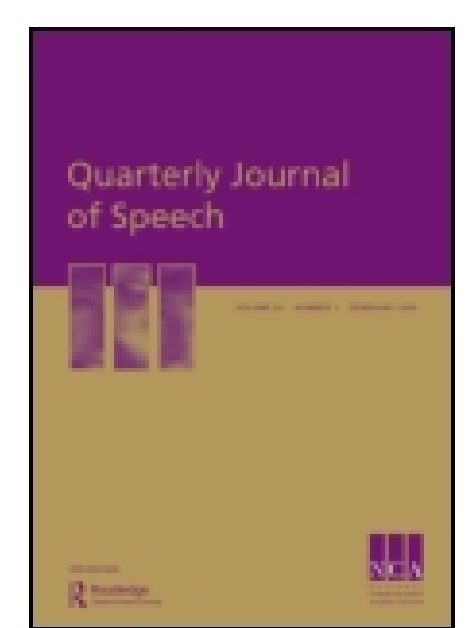

Quarterly J ournal of Speech

Publication details, including instructions for authors and subscription information:

http:// www.tandfonline.com/loi/ rajs20

\title{
The theater as an educational institution
}

Beatrice Humiston ${ }^{2}$

High School, Portage, Wis.

To cite this article: Beatrice Humiston (1919) The theater as an educational institution, Quarterly J ournal of Speech, 5:2, 120-127, DOI: 10.1080/00335631909360729

To link to this article: http:// dx. doi. org/ 10.1080/00335631909360729

\section{PLEASE SCROLL DOWN FOR ARTICLE}

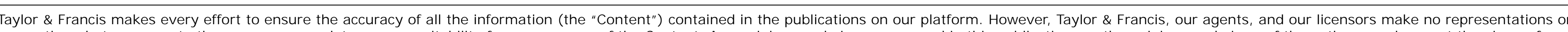

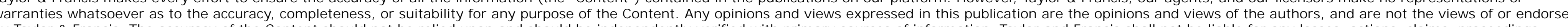

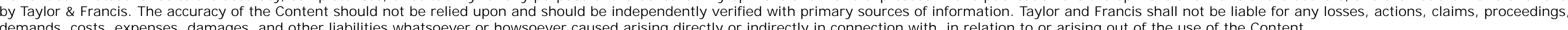
demands, costs, expenses, damages, and other liabilities whatsoever or howsoever caused arising directly or indirectly in connection with, in relation to or arising out of the use of the Content.

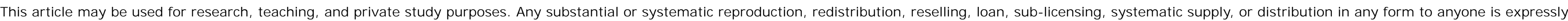
forbidden. Terms \& Conditions of access and use can be found at http://www.tandfonline.com/page/terms-and-conditions 
THE THEATER AS AN EDUCATIONAL INSTITUTION

BEATRICE HUMISTON

Portage (Wis.) High School

$\prod \mathbb{H E}$ number of attacks against the American theater at the present time would seem to indicate glaring faults in our theatrical system. Practically every book, every article, every lecture on the American theater decries it as a failure. Generally speaking, the charge is that the American theater, steeped in commercialism as it is, does not fulfil its highest duty to society. The conditions and limitations which commercialism has imposed upon our theater are many and far-reaching.

"The first application of the commercial system was an indication of progress, a benefit to the actor and to the production in general. It was organized as a means of successfully supporting the drama. It raised the author and the player from penury, and raised the theater to a plane of a self-respecting profession." "Competitive business among theatrical companies ought to be a stimulating thing. The trouble with the commercialized theater of today is that instead of supporting the drama, it has required the drama to support the system. Managers discovered that what had been a precarious trade of half-vagabondish players could, under organization, be magnified to a tremendous business of purveying entertainment to the appetites of newly awakened millions." As a result of this discovery, the American theatrical system has gone over entirely to "big business." Thirty years ago the great theatrical syndicate raised its portentous head in this country. Before that time the large cities scattered in different sections of the country, St. Louis, for instance, San Francisco, and Indianapolis, had their own independent producing theaters, which rivalled the things seen in New York. This independent competition was stifled by an appalling theatrical monopoly which started in New York, as a shrewdly organized booking company, to distribute touring companies throughout the cities of the United States. This action placed the entire control of our theater system in the hands of less than twenty men, a few New York producing managers whose aims determined and still determine largely what shall pass

1 Dickinson, Thomas, The Case of the American Drama, p. 94.

2Ibid. 
as dramatic art in all centers throughout the country where people gather for illusionment." As Sheldon Cheney puts it, "Unless these managers see fit to feed favored theaters with plays bearing the Broadway stamp of approval the whole country becomes a dramatic waste." ${ }_{4}$ So centralized and concentrated has the control of the theater become in the hands of a few producers that the theater monopoly has been able to fill its own theaters all over the country at its own prices with warmed-over New York successes without fear of competition in any form. It has been able to set a uniform price for practically all its performances, cheap or expensive to produce, without regard for importance or worth. ${ }^{5}$ It has been able to keep the same show running season after season reaping profits of hundreds of thousands of dollars. Under the monopoly system the gambling aspect of the theater business has developed. So profitable has centralization of theatrical control been found, that the exploiters have now become unwilling to keep going a production which brings them a profit of less than ten percent. "A play which does not realize this profit is discarded as a failure. Four failures out of five, then, must be paid for by the overwhelming profits of a single fifth production. Those plays which might earn two hundred dollars per week are killed off, therefore, to make room for other plays, frequently less worthy, that may earn of a profit of two thousand per week. Big business demands that a play in order to earn the privilege of a continuance of its existence shall reap a profit of several hundred percent of the original investment. Any project which demands a profit of more than ten percent is not business, but gambling." "And the professional gambler," says Sheldon Cheney, "is the last person in the world to take a risk So the Broadway producer, afraid above all else to play the game in a new way, repeats himself year in and year out, and New York spills to the four corners of the country an unending stream of musical comedies and revues, and crook plays and society farces."' Thus the commercial theater has subordinated all considerations of the drama to purely mercenary motives. A good play has come to mean a "successful" play, and a successful play to mean a play that

${ }^{3}$ Hopkins, Arthur, How's Your Second Act? p. 19.

4 Cheney, Sheldon, Editorial, The Road Town Problem. Theater Arts Magazine. December, 1917 , p. 47 .

${ }^{6}$ Matthews, Brander, What is the Matter with the Theater? Unpopular Review. January, 1917, p. 56.

6 Hamilton, Clayton, The Non-Commercial Drama. Bookman, May 1915, p. 276.

${ }^{7}$ Collier, John, The Theater of Tomorrow, Survey, Jan. 1, 1916, p. 385. 
earns enormous profits. The results of the capitalizing of entertainment have been deep-seated both as to society and art, and no phase of dramatic presentation has been unaffected. ${ }^{8}$

It is well to ask ourselves what it is that we are expecting from the theater and are not receiving. How far ought the theater to be serviceable to civilization? What are the duties which we claim we have a right to demand from the theater?

This statement may serve as a thesis for the following discussion: The public has a right to demand of the theater, necessary and inevitable as it is, and powerful as are its possibilities for good or evil, a definite, conscious educational influence.

In the first place we can not do without the theater. As an amusement, a form of relaxation and relief, it is a necessity. It meets a great human need, satisfying natural curiosity, the craving for excitement and the love of excursions into the world of imagination; 9 and allowing freedom from self-interest. The complexity of modern life, American life especially, taxes our supreme strength. For proper balance, for health of mind and body, we need relaxation. We need to let down and to let down often. America of all countries can not afford to neglect her institutions which provide relaxation. With the growth of the industrial classes and the growing tendency toward specialized labor, has come the danger of developing in our people a narrow precision and definiteness, an inclination to be over-practical, one-sided, and perhaps machine like. A great proportion of our population are office-workers and mechanics, the nature of whose work demands primarily concentrated attention to details. These men need, above all, a form of relief and relaxation which will open up new channels of expression, something to broaden their conceptions, something to free them from tenseness. Mr. Patrick in his book The Psychology of Relaxation says, "There must be large periods of relaxation from the high tension life of today. If they are not provided in the form of healthful and harmless sports there will be instability, fatigue, and social outbreaks."

The frightful movie craze is a form of relief which our people as a nation have eagerly grasped in their desperate need for recreation, for some sort of change from the monotony and strain of the

8 Dickinson, Thomas, The Case of the American Drama, p. 94.

- Curtis, Elnora Whitman, The Dramatic Instinct in Education, p. 27.

10 Patrick, G. T. W., The Psychology of Relaxation, p. 21. 
work-a-day world. Now the drama is able to afford a complete relaxation. It provides an outlet for pent-up emotions, giving rise to laughter and tears; it provides a generous reaction after strain or intense concentration; it breaks down inhibitions; it allows of self-forgetfulness. Even when the emotions aroused are unpleasant, the effect is often in the nature of relief rather than of strain, since the person in the audience is not personally related to the action. The sympathy and interest are with the heroine or hero; the specta'tor's fear of the villain, is after all, only in behalf of these people in the story, and because the spectator at the play is not directly and personally concerned with the action, he can share completely the experiences of the players without self-restraint, or selfconsciousness. And there is relaxation in getting outside oneself. The people need amusement as they need work and food and sleep to keep them sane and healthy. The theater as an effective form of amusement, then, is a social necessity which can not be ignored. The people created it, out of their necessity to satisfy their impulses, to indulge their leisure moments; they always will maintain it, even when it is unworthy, out of their necessity. And the joy of the theater as a human necessity is that it educates while it amuses. It establishes a constructive leisure. ${ }^{11}$ For it is in a man's leisure moments, when the bars are down, or, we may say, when he is off his guard, that he is most easily influenced, that his impulses are obeyed, that actions are simulated, that impressions are made upon him. And the man at the theater does not know that he is being educated - therefore he does not resent it. ${ }^{12} \mathrm{He}$ just sits in the audience and takes in his education unknowingly, as easily as he breathes. The efficacy of the theater's power lies in its irresistibility. Little children have a passion for a "show." Newsboys stand in front of playhouses and beg to be taken in. Even with the feeble-minded, the theater makes its appeal. ${ }^{13}$ No religious disapproval, no prudishness, no legal enactment, has been able to eliminate it from society. ${ }^{14}$ The theater is inevitable. It appeals to all classes of people because it appeals to the senses. Human beings cannot resist the spectacle of a play, they cannot resist the sound of it, they cannot resist the story. And because every-

${ }^{11}$ Burleigh, Constance, The Community Theater, p. 113.

${ }_{12}$ Stocking, Helen, Social Theater and its Possibilities. Overland Monthly, April 1916 , p. 268

${ }^{13}$ Collier, Hohn, The Theater of Tomorrow. Survey, January 7, 1916, p. 382.

14 Andrews, Charlton, Drama of Today, p. 207. 
body likes the theater, and never tires of it, the theater is democratic as no other institution ever can be. It is universally appealing and therefore universally powerful.

There are many sides to the theater as an educational force. We shall not go into a discussion of its very obvious educational advantages. It is perhaps generally recognized that the theater gives us information, historical, for instance, in a form which we can keep longer than we can keep information gained in any other way. It is natural that the stage should teach more effectively than literature, for instance, because we can not forget what we have learned by watching events as they might really have happened, by hearing words as they might really have been spoken, and we are very likely to forget what we have only read from a printed page. Education has come to include rather broad aspects, and the theater is unlimited in its possibilities for help. For one thing, in the theater lies the possibility of cultivating the taste of a nation. The theater is not only one art, but a combination of all the arts, the joint product of the efforts of all artists, musician, playwright, poet, composer, dancer, architect, sculptor, painter, and actor. ${ }^{15}$ And the arts come in a pleasant form at the theater. The refining influence "gets over," therefore, easily, without a struggle, to an unconscious and receptive audience. The man who would not enter an art gallery on his life, will go to the theater, for the music perhaps, or, perhaps, for a favorite actor. He will see a stage picture which is good, which has esthetic value, and he will have gained something in the experience. Frequent enjoyment of beautiful harmonious stage setting will cultivate in him at least something of a taste for line and color and light. It works on the principle which governs our reading. Grood books spoil bad ones for us. And so with the other arts. Served as they are in combination with each other we gladly accept a little of each, and while we are being pleasantly amused, we learn to appreciate.

"In all great art," says Charleton Andrews, "there is an unmistakable and emphatic ethical significance. . . A A growing popular taste for the stage means a growing popular appreciation of a potent means of helpful comment on life."16 "Fine art," says Bernard Shaw, "is the subtlest, the most seductive, the most effective means of morall propagandism in the world, excepting only the

${ }^{15}$ Burleigh, Constance, The Community Theaier, p. 113.

${ }^{16}$ Andrews, Charleton, The Drames of Today, p. 212. 
example of personal conduct." 17 Oscar Wilde's theory is that life imitates art, and Archibald Henderson adds that "a comparison of the wandering influence of the church with the waxing influence of the theater as a guide to conduct is a conspicuous verification of Wilde's suggestive theory." 18 Miss Jane Addams has made the following observation in connection with her social experience, "In moments of moral crisis now; the great theater-going public turns to the sayings of the hero who found himself in a similar plight. The sayings may not be profound, but they are at least applicable to conduct." 19 And Archibald Henderson comments again, "Indeed, we may go further and say that people of all classes in moment of emotional stress often unconsciously reproduce expression which they have heard their favorite heroes, heroines, and villains utter. Only a genius in the simple expression of elemental feeling, in a crucial situation is capable of giving voice to natural feelings as if he had never witnessed the work of dramatic or fictive art."20 Certainly we cannot ignore the influence which the acted drama has upon our moral conduct especially in our youth. The most impressive lesson we can learn comes through personal experience. Second only to that in effectiveness is living the experience in "makebelieve." Seeing and hearing the thing acted on the stage follows closely in significance. Miss Elnora Whitman Curtis in her book The Dramatic Instinct in Education cites several instances in which simple-hearted people have directly admitted the moral inspiration which the theater has given them. One girl who had been vitally interested in Portia of The Merchant of Venice, declared she wanted to be good now, " 'cause of her." It is easy to be indifferent to the statement we might read or hear, "The man who murders will be punished," but who can forget a story he bas seen impressively, grippingly acted in which a murderer suffers a terrible fate. When we consider how many of us go to the theater, and how often we go, and how closely associated the drama is with life, we can not deny that the theater will play a part in shaping the manners and morale of our people. In the words of Bernard Shaw, the theater forms "the mind and affections of men in such sort that whatsoever they see done in show on the stage, they will presently be doing in earnest in the world, which is but a larger stage." ${ }^{21}$ Thus far we have con-

17 Henderson, Archibald, The Changing Drama, p. 14.

18 Henderson, Archibald, The Changing Drama, p. 17.

19 Ibid.

20 Henderson, Archibald, The Changing Drama, p. 17.

21 Stocking, Helen, The Social Theater and Its Possibilities. Overland Monthly, April 1916, p. 272. 
sidered the theater as a public institution where people go to watch and listen. If we give it a broader significance and consider the theater as all dramatic production, we find its greatest educational influence, its highest developing power in the effect upon those people who participate in the acting, in amateur plays, in school plays, in "home talent shows" if you will. Amateur production is a force which can not be overestimated in the field of education. The large imitative factor in dramatic play of children makes it a rare educational instrument. ${ }^{22}$ Dramatization in connection with education has offered an outlet for self-expression to young people, an opportunity to break the fetters of self-consciousness, and to develop their dramatic instinct body, mind, and soul. ${ }^{23}$ Eleanor Robson in an article on The Theater and Education remarked, "There is no school like the school of experience. The playing of parts can be experience in living. "' ${ }^{24}$ An article by Miss Helen Stocking, The Social Theater and Its Possibilities takes the same point of view. Through dramatization, Miss Stocking contends, a child brought up in unfavorable environment may receive conceptions or ideals of taste, of properly spoken English, house furnishings, dress, school reform, in a word, the Art of Living. 25 Participation in dramatic forms presents possibilities for reforming and creating personalities. ${ }^{26}$ For it is not what goes into the man that develops him; it is the thing which comes out, the thing which is responded to by expression. Miss Stocking has observed that there is real value in assigning to a timid child the rôle of a character of confidence and courage, in allowing him to assume the qualities he lacks. Out of the make-believe, something will remain in the child's personality. The bad boy finds that it is quite as interesting to direct his energy and emotional bent into deeds of chivalry and heroic deeds as into crime. ${ }^{\prime 2} 27$ The children love the recreational exercise of their dramatic instincts, and there can be no doubt that grammar school pupils are gripped with a stronger power than even the movies can exert. ${ }^{28}$ In a word, dramatization is one of the most effective means of vital education.

22 Curtis, Elnora Whitman, Dramatic Instinct in Education, p. 99

${ }^{23}$ Stocking, Helen, The Social Theater and Its Possibilities. Overland Monthly, April 1916, p. 268.

${ }_{24}$ Robson, Eleanor, Theater and Education. Outlook, March 7, 1917, p. 412.

$25 \mathrm{Cf}$. note 24, p. 270

${ }^{26}$ Stocking, Helen, The Social Theater and Its Possibilities. Overland Monthly, April 1916, p. 270.
27 Ibid., p. 268.

${ }^{28}$ Welldr, Charles F., A Children's Playhouse. Survey, Feb. 19, 1916. 
But the effect of the theater bears a less tangible aspect. There is a certain influence which the drama exerts over the theater-going public and over the drama-acting public which is rather hard to define. There is a certain richness which the drama gives us in taking us now and then out of the commonplaceness and sordidness of our narrow experience. Mary Austin calls it one of the things which make up a "glamor-filled life." "The theater," she says, "is a form through which man expresses and expands his relation to the invisible forces. It is normal for man to live in an atmosphere of glamor. Under shadow or gleam of ideals, the human soul has its home. All children live thus, so do all primitives, so did most societies through most of history. It is thru glamor that men find deliverance, and all high motives are mythopoetic motives. A glamor-filled life is a life of dramatized relationships and dramatic consciousness. Through the deliberate use of dramatic powers, ideals may be changed, the quality of conscious life may be changed, and ultimately, as a matter of course, the direction of a social movement may be changed." ${ }_{29}$ Richard Mansfield once passionately said, "The stage is for poetry, for all the things some of us, lying on the grass, with our faces to the skylark, dream of on a summer day or on a moonlit evening; those things that come to us with a whiff of the balsam pine, or the touch of a soft hand, or the discovery of a withered flower. Poetry is in us always and will crop out in the most hardened of us, and where we should always see it, and where it will forever awaken all that was born good and beautiful in us, is upon the stage."

I have sketched briefly what the theater should be able to accomplish. As a necessary social force, as a perfect form of relaxation, it is in a position to teach more lessons to more people in a more attractive and stimulating way than is any other force. It is able to teach moral lessons more easily and more effectively than the church or the school, because its scope is unlimited, and because it reaches people when they are receptive and unrestrained, through the pleasing medium of story and music and spectacle. The theater is able also to cultivate artistic appreciation in a nation, as well as to develop an understanding of history, language, good speech, of ideals. The theater ought to be our most efficacious civilizing and nationalizing agent.

${ }^{29}$ Collier, John, The Theater of Tomorrow. Survey, Jan. 7, 1916, p. 833. 